\title{
Architecture of modern coastal development. Saint Petersburg realias and experience of Amsterdam, Rotterdam and Hamburg
}

\author{
Fedor Perov ${ }^{1, *}$, Leonid Lavrov ${ }^{1}$, and Aleksandra Eremeeva ${ }^{1}$ \\ ${ }^{1}$ Saint Petersburg State University of Architecture and Civil Engineering, Saint Petersburg, Russia
}

\begin{abstract}
Results of the first stage of territory development in the Gulf of Finland near the western coast of Vasilyevsky Island in Saint Petersburg are rated unsatisfactory. Results in the field of aesthetics, ecology, social stability and functional arrangement of the urban environment on new lands are negative. According to the analysis of experience in coastal areas' reconstruction in Amsterdam, Rotterdam and Hamburg, ambitious goals that were set for the project in Saint Petersburg were not achieved due to defects of the urban planning system - there was no centralized project management, activities of contractors, who neglected exclusive potential of the coastal area and its proximity to the historical core of the city, were insufficiently coordinated and controlled. It is argued that this is due to inertia of the Saint Petersburg design and construction system. During many years, it was focused on large-scale residential development of vast peripheral territories and, therefore, it was not capable to resolve issues related to development of highly urbanized environment in the city center. Omissions made during construction of a highway through the residential area are identified. The highway design does not provide reliable protection against negative impact on residential quarters. The route of the highway was designed as a bypass of the city center, but it became the shortest route to the center. It is noted that further development will offer opportunities for partial correction of the errors made. The new management team of the city architectural services considers the territory perspective for expansion of the Saint Petersburg center towards the water area of the Gulf of Finland.
\end{abstract}

\section{Introduction}

Nowadays, the development of coastal zones has become an important goal of urban development in dozens of metropolises of the world - from Sydney, Singapore and Dubai to Boston, Oslo or Marseille and Genoa. Saint Petersburg, considered the largest seaport in Russia, has traditionally developed in the Neva Delta, and only point settlements have developed on the coast of the Gulf of Finland. The main site of the trading port until 1885 functioned on Strelka, the eastern tip of Vasilievsky Island, and only from the middle of the 19th century, cargo berths began to move towards the bay.

\footnotetext{
*Corresponding author: f.perov@gmail.com
} 
Saint Petersburg has become one of the largest metropolises in Europe. Its population exceeded 5 million people, and the territory expanded to $1439 \mathrm{~km}^{2}$. Urban areas tightly cover the banks of the Neva Bay, and the system of highways provides travel along its entire perimeter (Fig. 1). This transport ring stretched in the latitudinal direction for about $40 \mathrm{~km}$. Therefore, since the mid-1990s, the idea was being worked out to cross the water area of the Neva Bay with an additional transverse route, to connect the northern and southern parts of the city by the shortest route.

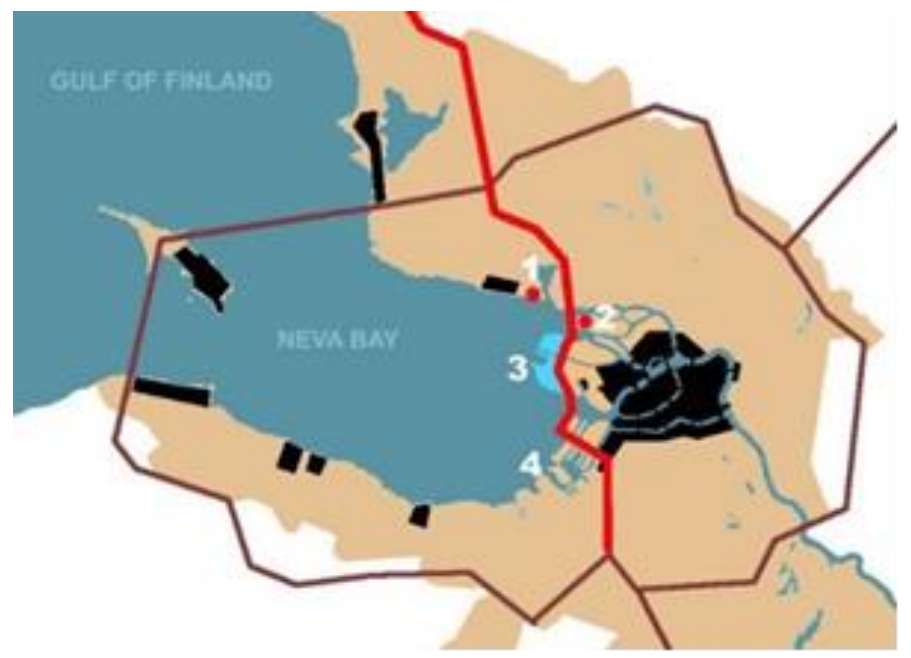

Fig. 1. Saint Petersburg as a seaside city. The color shows its territory within the administrative boundaries. The historical core and the centers of urban development on the shores of the Gulf of Finland are highlighted in black. The red line is the Western High-Speed Diameter. The numbers indicate: 1 - Lakhta-Center, 2 - Gazprom Arena stadium, 3 - reclaimed land of the "Marine Façade" with a passenger terminal, 4 - Big Port of Saint Petersburg.

In 2000, a decision was approved, according to which the main road called the "Western High-Speed Diameter" (WHSD) was to be laid along the coast of Vasilievsky Island, bypassing its territory. Such a strategic change in the transport framework significantly increased the attractiveness of the coastal territories and opened up new development prospects. In 2004, the Government of the Russian Federation decided to place the Passenger Port complex at the western end of Vasilievsky Island and connect it to the WHSD transport system. In 2005, the Administration of Saint Petersburg announced its intention to reclaim more than 400 hectares of land here with the aim of developing territories, building the "Marine Facade" and increasing the attractiveness of tourists to the city. In 2007, a master plan for development was approved.

The time has passed. In 2019, the deadline for the implementation of the project expires, but the results are not encouraging. Only $67 \%$ of the planned territory are reclaimed, construction is behind the schedule. There is no evidence that an environment attractive for residents and tourists is being formed here. Detailed projects do not cause positive emotions. The chief architect of the city is forced to note that not the ceremonial "Marine Facade" appears on the alluvium, but simply residential areas that are visible from the sea. 
There are no signs that iconic objects may appear here that will attract citizens with their unique functional capabilities or appearance. It is believed that the residential blocks that have appeared are devoid of individuality and reproduce the unified features of many outerlying residential district that fill the periphery of St. Petersburg. A zone adjacent to the WHSD motorway is in the area of ecological and social ill-being. Noise and dust degrade the quality of the environment over a wide area. The active stream of cars moving to Vasilievsky Island not only crowded the local streets, but also paved its way through residential neighborhoods, which causes protests from the population. A wide strip of WHSD divided the population of Vasilievsky Island into conflicting residents of the "mainland" part of the island and those living "in the enclave" (on the alluvium). It can be concluded that the results of urban development on the coastal territory of Vasilievsky Island in 2005-2019 do not correspond to the originally proclaimed goal and do not allow speaking of a positive assessment of what has been achieved.

\section{Methods}

The obvious failures with the formation of the "Marine Façade" of Saint Petersburg look like a unique incident and deserve to be compared with the successful experience of other coastal cities. It is noted that the exceptional potential of coastal zones began to attract modern urban planners only in the second half of the 20th century, but it was appreciated, which allowed a lot of new attractive and convenient urban areas to appear in a relatively short period of time [1]. It is proposed to compare information on urban development activity in the reclaimed territory in Saint Petersburg with data on the development of coastal zones in large European metropolises. Amsterdam, Hamburg and Rotterdam located on the flat coast of the North Sea may be the most suitable objects of analysis - they are comparable with Saint Petersburg in terms of population, the nature of urbanization, and hydro-geological conditions.

Table 1 shows the initial reference data of the coastal regions of European cities [2, 3, 4, 5], and Fig. 2 - planning schemes of these areas and the territory of the "Marine Facade" of Saint Petersburg.
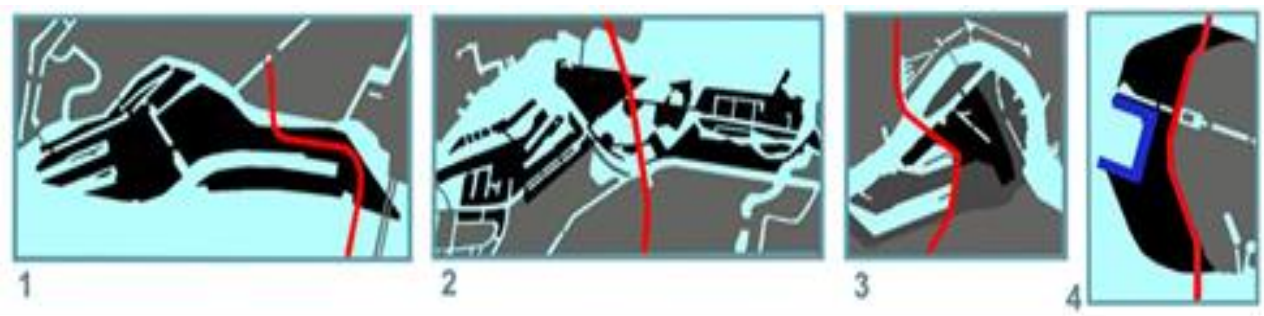

Fig. 2. Schemes of coastal zones: 1 - Hamburg (HafenCity), 2 - Amsterdam (IJburg), 3 - Rottedam (Kop van Zuid), 4 - Saint Petersburg ("Marine facade"). Red lines indicate highways, blue lines - port territory. 
Table 1. Reference data on coastal areas of European cities.

\begin{tabular}{|c|c|c|c|c|}
\hline \multirow[b]{2}{*}{ City and region } & \multicolumn{4}{|c|}{ Indicators } \\
\hline & Area (ha) & Housing stock & Workplaces & Significant architectural objects \\
\hline $\begin{array}{l}\text { Hamburg, } \\
\text { HafenCity }\end{array}$ & 240 & $\begin{array}{l}14 \text { thousand } \\
\text { inhabitants }\end{array}$ & $\begin{array}{l}45 \text { thousand } \\
\text { jobs }\end{array}$ & $\begin{array}{c}\text { Reconstructed Speicherstadt, } \\
\text { Elbphilarmonie, HafenCity } \\
\text { Universität, Marco-Polo-Tower } \\
\text { \& Unilever-Haus }\end{array}$ \\
\hline $\begin{array}{l}\text { Amsterdam, } \\
\text { IJburg } \\
\text { (Steigereiland + } \\
\text { Haveneiland } \\
\text { +Rieteilanden) }\end{array}$ & 2380 & $\begin{array}{l}45 \text { thousand } \\
\text { inhabitants } \\
18 \text { thousand } \\
\text { apartments }\end{array}$ & $\begin{array}{l}12 \text { thousand } \\
\text { jobs }\end{array}$ & $\begin{array}{l}\text { ARCAM Centre for } \\
\text { Architecture, Public Library } \\
\text { Amsterdam, Music Building on } \\
\text { the IJ, Nemo museum, EYE } \\
\text { Film Instituut Nederland, } \\
\text { IJDock Multifunctional Center, } \\
\text { residental building Silodam, } \\
\text { A'DAM and IJ Tower } \\
\text { skyscrapers, Waterbuurt } \\
\text { quarter of floating houses }\end{array}$ \\
\hline $\begin{array}{l}\text { Rotterdam, } \\
\text { Kop van Zuid }\end{array}$ & 270 & $\begin{array}{l}755 \text { thousand } \\
\mathrm{m} 2 \text { of living } \\
\text { space (5300 } \\
\text { apartments) } \\
15 \text { thousand } \\
\text { inhabitants }\end{array}$ & $\begin{array}{l}380 \text { thousand } \\
\mathrm{m} 2 \text { of office } \\
\text { space } 18 \\
\text { thousand jobs }\end{array}$ & $\begin{array}{c}\text { Erasmus Bridge, New Luxor } \\
\text { Theater, reconstructed Hotel } \\
\text { New York, towers of Maas, } \\
\text { KNP, World Port Center, } \\
\text { Montevideo, New Orleans, The } \\
\text { Rotterdam (The largest } \\
\text { building in the Netherlands), } \\
\text { Spoorweghaven } \\
\text { Multifunctional Center }\end{array}$ \\
\hline
\end{tabular}

\section{Results and discussion}

Below you can find information about the element-by-element comparison of these coastal zones and the circumstances of their formation.

\subsection{Harnessing the potential of the water area ("Water View")}

City-planning theories emphasize that for the development of coastal zones, the decisive factor is the close interaction of buildings and water areas. Experts argue that even readymade projects allow "making money on one simple fact - people like to spend time near the water" [1]. In Fig. 2, you can see how the coastal zones of coastal cities in Western Europe are dissected (schemes 1,2,3), and statistical data allow estimating the value of the water area potential:

- in the Hafen City complex in Hamburg, the length of the coastline exceeds $10 \mathrm{~km}$;

- the total area of the Kop van Zuid area in Rotterdam is 640 ha, of which the water surface is $370 \mathrm{ha}$; 
- the territory of the IJburg district in Amsterdam is 2380 ha, of which 490 ha are in the water area.

In Saint Petersburg, as a result of alluvium, the contacts of the residential zone with the water area decreased. Scheme 4 in Fig. 2 shows that the new coastline repeats the existing ones, but urban development can approach the water edge only at two peripheral segments, since the central part of the water front is given to the port complex.

\subsection{Functionality and image characteristics}

The coastal areas in Amsterdam, Hamburg and Rotterdam were built up as residential areas, based on the fact that "coastal areas are ... the most demanded land in the city, which is used not only for parks, but also for museums, tourist sites, recreation places, as well as for commercial and residential development" [1]. Table 1 indicates that, in addition to residential buildings and related social infrastructure objects, objects of unique, citywide significance were placed as a means of regulating urban development processes (their construction increases the value of adjacent land, attracts business centers and luxury housing). Therefore, representative public buildings became the first new buildings on new lands of Amsterdam. Significant objects are given exceptional importance, their role in the formation of the city's brand is taken into account, therefore extraordinary conditions are allowed during their construction.

In the project of the Hafen City in Hamburg, it was clearly defined that a fifth of the territory was allocated for socially important objects (parks, squares, churches) and buildings of cultural, scientific and educational purposes [2]. However, the rigidity of such regulations receded into the background when it came to the unique Elbphilarmonie: 866 million euros were spent on its construction with an initial estimate of 77 million, and the construction period was increased by 6 years.

In Rotterdam, the Erasmus Bridge was built according to the most expensive, but the most expressive of the competitive options. Financial support was provided by the Government of the Netherlands [5]. Focused work on the architectural image is paying off, and now the new coastal areas have received recognition not only from specialists, but also from tourists.

Saint Petersburg is distinguished by the fact that more than $15 \%$ of reclaimed land is allocated to external transport facilities - the Sea Port and highway, while the configuration of the WHSD motorway and the location of the port were determined only with the nominal participation of architects. In Saint Petersburg, land reclamation and its development began at the Marine Station, but there was no significant building designed for the attention of arriving tourists and attracting interested investors to new territories. Several small utilitarian pavilions were considered sufficient. This approach was also decisive in the future. When adjusting the project in 2014, all attention was shifted exclusively to housing, the number of public and business facilities was reduced. Nowadays, there is not even a place reserved for any distinguished structure, everything is limited to the standard set of objects for local trade and consumer services.

\subsection{Social indicators of the urban environment}

Table 1 shows that in the residential zone of European cities, a significant place is given to the territories of workplaces. In the Netherlands, the country's government financially supports development projects, if such a factor is taken into account. The structure of the created housing stock is planned in accordance with the requests and capabilities of all groups of citizens. It is taken into account that the mechanisms of the apartment market 
contribute to forcing out housing for low-income families from attractive coastal territories, especially central regions. The balance of housing classes is regulated and monitored:

- Kop van Zuid was formed as part of the center of Rotterdam, but the number of homes for prosperous families in this area should not exceed $50 \%$ of the total. The message was received with alarm that, as a result of gentrification, the proportion of elite apartments increased to $70 \%$;

- in the project of IJburg (Amsterdam), a balance characteristic for the peripheral zone was taken into account: $30 \%$ - social rent, $40 \%$ - rent for the middle class, $30 \%$ - private tenement housing;

- when the results of the first phase of the Hafen City project in Hamburg were summed up in 2010, it was considered that there was a kind of "luxury ghetto" with luxurious apartments and a few accessible services. To achieve social sustainability, the city authorities determined that at a subsequent stage, $30 \%$ of the new housing stock should be rented apartments with a moderate charge.

The initial concept of the "Marine Façade" in Saint Petersburg developed the idea of creating a multifunctional complex on the alluvium. It was planned to provide a sufficient number of jobs, which reflected the established balance of territories: 85.4 ha for housing, 66 ha for public and business facilities. However, soon the project was handed over to private investors, and the situation began to develop unpredictably. In contrast to Western European cities, residential blocks designed for customers with minimal financial resources appeared first in the "Marine Facade" of Saint Petersburg. The situation was affected by the housing market and the attractiveness of the "quick money" system for developers. There are no objects of social infrastructure or a road network on the reclaimed lands, but 2600 economy class apartments with a total area of 80 thousand square meters (i.e. an average of 30 square meters per apartment) have already been occupied, and it is planned to transfer another 6,800 such apartments to buyers.

Now the market has begun to show interest in comfortable housing in this area - good transport links with Lakhta-Center have an impact. It is difficult to predict what new architectural complexes will appear here and how the neighborhood of contrasting types of housing will develop.

\subsection{Ecology}

The reconstruction of coastal areas in Hamburg and Rotterdam turned the territories of the former berths and warehouses into a residential zone and, accordingly, improved their environmental performance. Great attention was paid to the city transport routes, which are considered the strongest source of negative impact on the ecology of the residential zone of the city. On the territory of Hafen City, a busy transport corridor remains in its eastern part (Scheme 1, Fig. 2). After processing a number of concepts, an option was found when nonresidential facilities were placed on the site adjacent to this highway from the north. And from the south of it, noise-proof quarterly layout schemes were used in the construction. In Amsterdam, where the ring road crosses the territory under development (Scheme 2, Fig. 2), a decision was made to minimize its contacts with the living environment. In Rotterdam, the sections adjacent to the highway were used for office buildings.

The experience with building WHSD at the western end of Vasilievsky Island demonstrates the negative consequences of the rejection of normative recommendations: of "the complete isolation of the main traffic flows from adjacent buildings, as well as local traffic" [6].

The strategic plan in Saint Petersburg (2000) was unprecedented - a busy highway (4 lanes on each side, a large proportion of heavy trucks with diesel engines, speed of 110 $\mathrm{km} / \mathrm{h}$ ) had to go five kilometers from the core of the historic center. Obviously, the 
environmental situation in this part of the city was heavily impacted. The urban planning solution adopted in 2007 exacerbated the situation - for over $2 \mathrm{~km}$, the highway rolled out residential territory with existing and planned multi-story building blocks (Fig. 3).

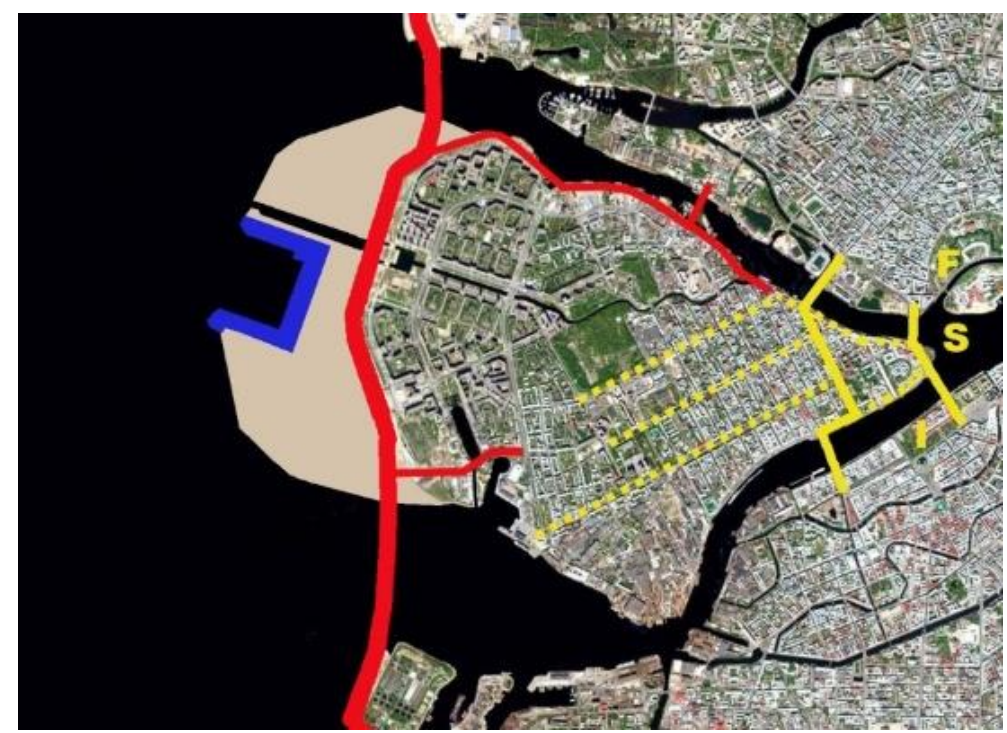

Fig. 3. Scheme of reconstruction of Vasilievsky Island. The red line shows the new highways, yellow - the main transport routes of the historical center, blue - the Sea Port. F - Peter and Paul Fortress, S Strelka, I - St. Isaac's Cathedral.

The technical solution of the highway laid along Vasilievsky Island became concordant - a trench of 6 meters deep with gently sloping green slopes cut off the enclave of reclaimed land from its mainland. The entire western part of Vasilievsky Island, which differed from other areas of the center by a relatively low level of noise and gas contamination, is now in the range of negative impact of WHSD motorway. Not far from the center of the fivemillion-strong metropolis, a solution has been implemented that is common in low-urban areas with low-rise buildings. It took more than 30 hectares of territory, considerable investment, but sound waves turned out to be directed to the upper floors of buildings (Fig. 4). The experience of minimizing environmental risks in regions where more attention is paid to the fight against traffic noise was ignored (Fig. 5). 


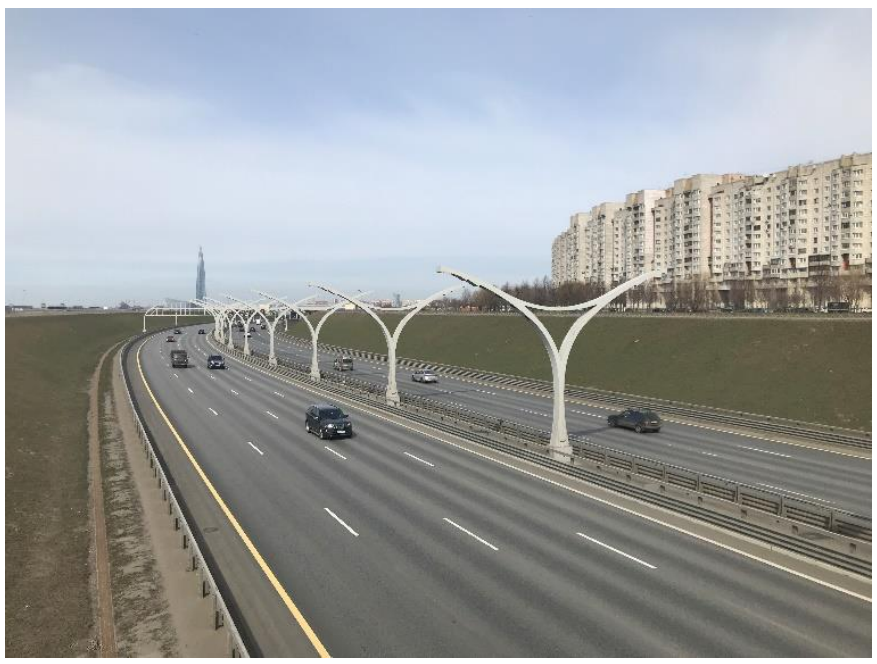

Fig. 4. Western High-Speed Diameter Motorway, Saint Petersburg.

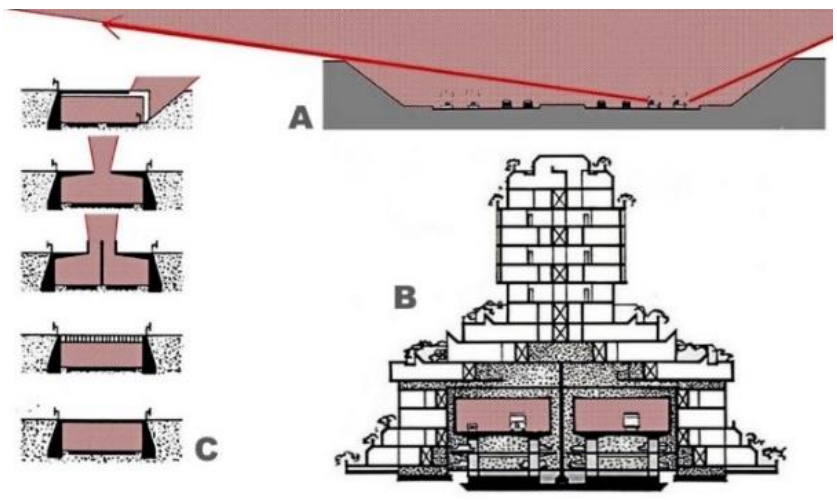

Fig. 5. Noise protection of highways in urbanized areas (the zones of sound pollution are highlighted): A - cross section of WHSD on Vasilievsky Island, B - housing, enclosure (German Einhausing) in the Schlangenbader Straße residential complex, Berlin, C - recommended types of route insulation in Germany.

It remains only to agree with the opinion of experts: "the environmental side of this project, including the "noise" side, is subject to serious revision" [7].

\subsection{Financing and project management}

Complex development projects abroad are implemented under tight control and with the participation of the authorities.

In Hamburg, HafenCity Hamburg GmbH was created to manage the project, which remains wholly owned by the city. Private investment in the Hafen City project is 8.5 billion euros, and the city's contribution is 2.5 billion euros, but in the form of building plots. Through land distribution, city authorities can have a decisive influence on the development of the situation.

The reconstruction of Rotterdam is part of the National Programme for South Rotterdam (Nationaal Programma Rotterdam Zuid) [8], which was created and financed by the Central Government of the Netherlands for social problems (healthy environment, affordable housing, jobs, education, fighting crime, etc.). 
In Saint Petersburg, the coastal zone developed along three independent paths, which was reflected in the conditions of financing and project management:

- in 2005, work on the formation of the Sea Port began. The first ship docked here in 2008. The project finished in 2011. The management company "Marine Facade" spent about 9.5 billion rubles on the project (approximately 150 million dollars);

- the construction of WHSD also began in 2005. The central section, including Vasilievsky Island, was final. It was commissioned in 2016. The project included three high-water bridges, and costs reached 128 billion rubles (approximately 2 billion dollars);

- in 2006, the city ceded the right to reclaim and develop a coastal section of the Gulf of Finland with an area of 477 hectares to a large construction company for $\$ 5.35$ million (in comparison with the data listed above, the amount looks symbolic). The owner reclaimed the land in the southern part of the complex, then divided it into plots and sold it to 5 developers. This commercial decision changed the planned nature of the territory development. It did not go according to a single schedule, but in accordance with the specificity of the interests of each of the construction companies. Coordination of efforts turned out to be impossible, considerations of the municipal urban development level have faded into the background. The architect's field of activity was reduced. There was less and less space for artistic and aesthetic ambitions. Such a situation is described by the urban theoretician: "The greatest thing that was allowed to the architect was to apply external decorations to a form that could not be changed due to prevailing conditions" [9]. In 2009, the reclamation stopped, the northern part of the coastal zone now remains under water, and its fate has not yet been decided.

\subsection{Considering the interests of surrounding areas ("Good Neighborhood")}

The concept of urban reconstruction adopted in the Netherlands contains "mutual benefit" programs and requires that renewed areas improve the quality of life in the surrounding area. In Amsterdam (as in Hamburg), where the reconstructed territories are isolated from neighboring ones by waterways, such considerations played only a limited role, and much attention was paid to them in Rotterdam. Here, the liquidation of the port reduced the environmental burden, created offices and public facilities gave new jobs, transport and retail services improved. Nevertheless, the achieved results are criticized and therefore further development of this area is expected.

The administration of Saint Petersburg also considers it important that "construction means both comfort and harmonious development for both new settlers and residents of already built-up territories" [10]. As shown earlier, urban development of reclaimed territories negatively affected the ecological state of the western part of Vasilievsky Island, especially in the quarters adjacent to the WHSD motorway. The market reacted to this by lowering apartment prices and falling liquidity.

However, a strategic change in the transport framework of the city intensified urban development in the area. The influence of the Western High-Speed Diameter on the development of Vasilievsky Island recalls the dynamic transformation of the Petrograd side after the launch of the Trinity Bridge. Urban densification began on the eastern side of the motorway. It turned out that the city needed public and business facilities, which were rejected during the development of the building concept in 2014: a huge business center is being built on the Skipper Canal, an elite hotel is planned nearby. A cultural and leisure center is rapidly developing in the neighborhood: while it occupies 4 hectares of the coastal territory of the former plant, but plans to master all 15 hectares. "Theater of Songs" ordered by the Moscow star is trying to receive a building permit. Demand for housing in a settled urban environment is stable, and new elite neighborhoods are developing all available sites. 
Experts predict that Vasilievsky Island may expect a real construction boom in a few years [10].

\section{Conclusion}

A comparison of information on the formation of coastal zones in Saint Petersburg and Amsterdam, Rotterdam, Hamburg showed that there is a significant difference in the attitude to the whole group of concepts determining the development, and that the design and construction complex of Saint Petersburg is not ready to solve important urban problems related to aesthetics of development and its social content. The results of the formation of the "Marine Façade" are regrettable. For three quarters of a century in Leningrad - Saint Petersburg, the urban development process has been focused on the problems of mass housing construction, and the objects of its activity were large residential areas of the peripheral areas of the city [11]. There was no place for such a scale in the city center. As a result, when developing a unique coastal part of the city center on Vasilievsky Island, the approach already honed on the periphery of Saint Petersburg became the determining factor.

We recall the successful experience of developing the eastern end of Vasilievsky Island at the beginning of the 19th century, when a specially created management company played an important role. Then the solution of the utilitarian tasks of expanding the port complex led to the appearance of a representative architectural complex on Strelka. As in modern European practice, development of construction followed conceptual guidelines, was ensured by appropriate management and financing, and the potential for interaction with the water was actively used [12].

The implementation period of the "Marine Facade of Saint Petersburg" project is planned to be extended until 2026. The basic concepts of the general plan of Saint Petersburg, which is currently being developed, provide for the corresponding development of the city's urban framework with the formation of new public and business zones on the coast of the Gulf of Finland, on the Vasilyevsky Island at the mouth of Smolenka River, in the area of the Skipper Channel. The reclaimed territories, as well as the entire west of Vasilievsky Island, open up the prospect of saturating them with social and business functions, turning them into an integral part of the center of Saint Petersburg. The developers of the new general plan of the city believe that the Russian Northern capital should take its rightful place in the constellation of large European cities, and the formed urban environment should be focused on European quality standards.

The materials of the paper make it possible to clarify the content of these standards and the ways of their use at the new stage of the formation of the "Marine Facade" of Saint Petersburg.

\section{References}

1. V. Rybchinsky, Urban Designer. Ideas and cities (217, Strelka press, Moscow, 2014)

2. Amsterdam Ijburg, Abitare, 417, 196-197 (2002)

3. D. Meyhöfer, Hafencity Hamburg Waterfront: Architekturführer. Architectural Guide Hamburg, Verlag, Junius, 320 (2014)

4. S. Heller-Jung, Architekturführer Amsterdam (252, DOM-publishers, Berlin, 2012)

5. Rotterdam, Netherlands: Reconstruction of the Kop van Zuid area https://www.ereading.club/chapter.php/104260/9/Glazychev_-_Urbanistika._chast $\% 27$ 2.html (reference date: 20.03.2019) 
6. Recommendations for the modernization of the urban transport system (MDS 302.2008), RAACS, Central Research Institute for Urban Planning, Moscow (2008) https://ohranatruda.ru/ot biblio/norma/243578/ (reference date: 10.04.2019)

7. A. Zagorskaya, Journal of Civil Engineering, 5 (15), 44-48 (2010)

8. Nationaal Programma Rotterdam Zuid, Extra financiële impuls voor Rotterdam Zuid https://www.woningverhurenrotterdam.nl/nationaal-plan-voor-rotterdam-zuid/ (reference date: 10.01.2019)

9. V. Ostrovsky, Modern urban planning (359, Stroyizdat, Moscow, 1977)

10. I.N. Albin, General plan of St. Petersburg 2019-2043: strategy and tactics https://cyberleninka.ru/article/n/generalnyy-plan-sankt-peterburga-2019-2043strategiya-i-taktika (reference date: 10.01.2019)

11. F. Perov, L. Lavrov, Proceedings of the Institution of Civil Engineers: Urban Design and Planning, 168 (5), 259-266 (2015)

12. A. Eremeeva, L. Lavrov, Transportation Research Procedia, 36, 418-426 (2018) 